\title{
Errata - ¿Podemos Mejorar La Cicatrización de un Desgarro Muscular Masivo?
}

\section{Erratum - Can We Improve the Healing of a Massive Muscle Tear?}

\author{
Alex Vaisman Burucker ${ }^{1}$ Maximiliano Scheu Goncalves ${ }^{1}$ Ignacio Araya Proboste ${ }^{2}$ Rafael Calvo Mena ${ }^{2}$ \\ David Figueroa Poblete ${ }^{1}$ Marcela Gallegos Angulo ${ }^{3}$ Rafael Calvo Rodríguez ${ }^{1}$ Paulette Conget Molina ${ }^{4}$
}

${ }^{1}$ Departamento de Ortopedia y Traumatología, Facultad de Medicina Clínica Alemana Universidad del Desarrollo, Santiago, Chile

Address for correspondence Alex Vaisman Burucker, MD, Avda. Vitacura 5951, Vitacura, Santiago, Chile

2 Médico General, Facultad de Medicina Clínica Alemana Universidad (e-mail: avaismanb@hotmail.com).

del Desarrollo, Santiago, Chile

${ }^{3}$ Staff de Anatomía Patológica, Clínica Alemana de Santiago,

Santiago, Chile

${ }^{4}$ Facultad de Medicina Clínica Alemana Universidad del Desarrollo,

Santiago, Chile

Rev Chil Ortop Traumatol

\section{ERRATUM}

Rio de Janeiro, 30 de abril de 2018

Estimados lectores,

En el artículo ¿Podemos Mejorar La Cicatrización de un Desgarro Muscular Masivo?, publicado en Rev Chil Ortop Traumatol 2018;59:10-15 (doi: 10.1055/s-0038-1641564), en el Resumen, donde se lee:

"Las lesiones meniscales son las lesiones (...) ligamento cruzado reconstruido."

Debería ler:

Objetivos Evaluar macroscópica e histológicamente la cicatrización muscular utilizando Dexametasona (DEX) o Traumeel (TRM), en un modelo experimental animal.

Material y Métodos Estudio experimental en 45 ratones BKS. Se seccionó transversal y completamente el cuádriceps derecho en todos los animales. Se definieron 3 grupos de estudio de 15 ratones cada uno, un grupo control, un grupo tratado con Dexametasona y uno con Traumeel. Los animales fueron sacrificados a las 1,2 y 4 semanas después del procedimiento y se les extrajo ambos cuádriceps (derecho como intervención e izquierdo como control) y luego fueron analizados macroscópica e histológicamente por un patólogo calificado, de manera ciega. Los datos se analizaron estadísticamente con el test de Kruskal Wallis ( $\mathrm{p}<0,05)$, utilizando el programa Stata V12.1.

Resultados Macroscopía: A la semana, en todos los grupos se evidenció ausencia de cicatrización con gap persistente. A la segunda semana, se evidencia cicatrización inicial sin gap en todos los grupos. A las 4 semanas todas las muestras estaban cicatrizadas. Histología: La administración de Dexametasona disminuye el infiltrado inflamatorio y aumenta las fibras regenerativas, pero induce mayor fibrosis y pérdida de masa muscular. La adición de Traumeel aumenta la cantidad de fibras regenerativas, pero incrementa el infiltrado inflamatorio.

Conclusiones A las 4 semanas ninguno de los grupos de estudio presentó regeneración muscular completa, con resultados macroscópicos e histológicos variables.
Copyright $\odot$ by Thieme Revinter

Publicações Ltda, Rio de Janeiro, Brazil 
Rio de Janeiro, April 30, 2018

Dear readers,

In the article ¿Podemos Mejorar La Cicatrización de un Desgarro Muscular Masivo?, published in Rev Chil Ortop Traumatol 2018;59:10-15 (doi: 10.1055/s-0038-1641564), in the Abstract where it reads:

"Meniscal tears are the most (...) reconstructed ACL."

It should read:

Objectives To macroscopically and histologically evaluate a muscle strain healing model, using Dexamethasone and Traumeel.

Materials and Methods Experimental study in 45 BKS mice. 3 groups of 15 mice were defined: control group, Dexamethasone treated group and Traumeel treated group. The animals were sacrificed at the 1st, 2nd and 4th week, both quadriceps were resected (right as intervention and left as control) and then analyzed macroscopically and histologically by a qualified and blinded pathologist. Results were analyzed statistically using Kruskal Wallis test $(\mathrm{p}<0.05)$.

Results Macroscopy: the first week, all groups showed absence of healing with persistent gap. At the 2nd week, evidence of initial healing without gap in all groups. By week 4, all samples were healed. Histology Dexamethasone decreased the inflammatory infiltration and increased the regenerative fibers, but induced a higher fibrosis and loss of muscle mass. Traumeel increased the amount of regenerative fibers and the inflammatory infiltration.

Discussion The results of our study fail to define a definitive posture. We observed that Traumeel actually increases the amount of regenerative fibers and contrary to the literature, it increases the inflammatory infiltrate. On the other hand, Dexamethasone showed similar results in both regenerative fibers, fatty infiltration and muscle mass, but with increased necrosis.

Conclusions By the 4th week none of the groups showed complete muscle regeneration with macroscopic and histological variable results. 